\title{
Development of Android-Based Tourism Education Application
}

\author{
Ratri Rahayu ${ }^{1}$, Alif Catur Murti ${ }^{2}$ \\ \{ratri.rahayu@umk.ac.id ${ }^{1}$, alif.catur@umk.ac.id² \\ ${ }^{1}$ Mathematics Education Study Program, Faculty of Teacher Training and Education, Universitas \\ Muria Kudus Gondang Manis PO. BOX 53 Bae, Kudus, Central Java, Indonesia \\ Phone (+62291) 438229, Fax (+62291)437198 \\ ${ }^{2}$ Informatics Engineering Study Program, Faculty of Engineering, Universitas Muria Kudus \\ Gondang Manis PO. BOX 53 Bae, Kudus, Central Java, Indonesia Phone (+62291) 438229, Fax \\ $(+62291) 437198$
}

\begin{abstract}
The world of early childhood education was now experiencing changes, along with the rapid development of technology. This causes the need for human resources who master the latest technology in order to create an attractive technology-based media. The Android-based smartphone is the technology that currently inseparable and almost owned by everyone, both educators and parents are an. Android is an operating system that holds market share because it is based on open source and is always updated with new capabilities. Utilizing this technology as a means of making media in the form of electronic modules was an effort to improve education and support paperless activities. Children were not inconvenienced in carrying a large number of book-shaped modules when conducting educational activities, because they have been replaced with electronic modules that can be operated on an Android-based smartphone.
\end{abstract}

Keywords: Android, Early Childhood Education, Paperless, Smartphone, Tourism Education Module

\section{Introduction}

Early childhood education is a form of education that focuses on laying the foundation for physical growth and development (motor coordination, fine, and rough), intelligence (power of thought, creativity, emotional intelligence, spiritual intelligence), socio-emotional (attitude and behavior) and religion), language and communication, in accordance with the uniqueness and stages of development that are passed by early childhood. Early childhood education has been widely developed in the community, both developed and developed by government agencies and by the community, such as Toddler Family Development which was developed by National Population and Family Planning Agency, Child Care by social department, Kindergarten by Ministry of Education, daycare by Ministry of Religion, and Play Group by the community. Parents' awareness of the importance of education for early childhood is increasing. Early childhood education continues to increase from year to year [1].

Data on the number of children in 2002 aged $0-6$ years (28,311,300 people), only $5.69 \%$ served by kindergarten, $11 \%$ had entered elementary school and $52.25 \%$ were fostered through the Toddler Family Development Program. The remaining 30.06\% have not received educational services. However, in 2005, UNESCO noted that early childhood education programs participation rates in Indonesia occupy the lowest position in the world (20\%). The 
same phenomenon also occurs in ASEAN, Indonesia was classified as low compared to Vietnam, the Philippines, Thailand and Malaysia [2].

Follow-up is needed related to the facts above, by reviewing the main objectives of early childhood education. Forming quality Indonesian children, namely children who grow and develop according to their level of development so that they have optimal readiness in entering basic education and wading through life in adulthood.

The role of early childhood education programs teachers becomes important to be a figure that becomes the main foundation in achieving the objectives of early childhood education. So important is the role of the teacher in learning that requires teacher professionalism. Professional early childhood education programs teachers certainly have educational academic qualifications that are in accordance with government regulations. Academic qualifications of early childhood education programs teachers: have a $4^{\text {th }}$ diploma (D-IV) or Bachelor in the field of early childhood education obtained from an accredited study program, or have a $4^{\text {th }}$ (D-IV) or another relevant educational degree or psychology obtained from an accredited study program and has a early childhood education programs Teacher Professional Education Certificate from an accredited tertiary institution [3].

Not only educational qualifications, but the need for pedagogical competence is also an additional ability that teachers must have in managing student learning. Where at least contains the following things: a) understanding insight or basic education, b) student understanding, c) learning design, d) implementing learning that is educational and dialogical, e) the use of learning technology, f) evaluation of learning outcomes and g) student development [4].

In supporting the management of early childhood education programs teacher student learning can also create media using the latest technology that can be operated using an Android-based smartphone. The need to contribute to the use of technology because in the implementation of early childhood education should use the principles: (1) oriented to the needs of children; (2) learning through play; (3) conducive environment; (4) using integrated learning; (5) developing various life skills; (6) using a variety of educational media and learning resources; (7) carried out gradually and repeatedly [5]. Based on this description, early childhood education programs learning requires educational media and learning resources to support learning.

Smartphones are a primary need for the community, especially teachers, to be used as a medium to obtain scientific resources. Based on digital marketing research agency Emarketer, estimates that in 2018 the number of active smartphone users in Indonesia will be more than 100 million. With such a large number, Indonesia will become the country with the fourth largest active smartphone user in the world after China, India, and America [6].

Smartphone ownership by teachers is not supported by the ability to develop applications that can support learning. the results of an interview with the Chairman of the Indonesian early childhood educators association of Kalinyamatan District, early childhood education programs teachers have never received training on making android-based applications. Therefore, most teachers are only application users, not as developers. In fact, if the teacher is able to make their own learning application it will be easy to relearn the learning design that has been made. Not only beneficial for teachers, but the benefits of using learning applications can also be felt by parents. Monitoring of learning activities can be done in an easy way through a smartphone.

\section{Theoretical Review}

\subsection{Early Childhood Education}


Early Childhood Education is a process of growth and development. Children are born up to six years, discussing physical and non-physical aspects, by providing stimuli for optimal physical, spiritual, motor, mind, emotional and social development [7] [8].

\subsection{Android}

Android is a collection of software for mobile devices that includes operating systems, middleware and major mobile applications. Android has four characteristics [9] as follow:

\subsubsection{Open}

Android was built to be truly open so that an application can call one of the core functions of the phone such as making calls, sending text messages, using the camera, and others. Android uses a virtual machine specifically designed to optimize memory resources and hardware contained in the device. Android is open source, can be freely expanded to include new technologies that are more advanced when the technology appears. This platform will continue to develop to build innovative mobile applications.

\subsubsection{All applications are the same}

Android makes no difference to the main application from the phone and third-party application. All applications can be built to have equal access to the ability of a telephone to provide users with extensive services and applications.

\subsubsection{Resolve obstacles in the application}

Android breaks down barriers to building new and innovative applications. For example, developers can combine information obtained from the web with data on someone's mobile phone such as user contacts, calendars, or geographical locations.

\subsubsection{Fast and easy application development}

Android gives users very broad access to libraries and necessary tools that can be used to build better applications. Android has a set of tools that can be used to help developers increase productivity when building applications that are made.

\subsection{Tourism Education}

Tourism Education is a conscious and planned effort to create a learning atmosphere and learning process so that students actively develop their potential to have the spiritual spiritual strength, self-control, personality, intelligence, and skills needed by the community. Educational tourism itself is a type of special interest tour which is categorized according to specific motivations which are usually related to time, hobbies and the pursuit of free time, where there is a merging of recreation and education [10],[11],[12]. 


\section{Method}

The method used in building Android-based tourism education applications is Waterfall developed by Roger S. Pressman. Where the development steps are as follows [13]:

\subsection{Analysis}

The analyst stage is the stage where we find out the needs, the flow of the program or story board of the educational application made.

\subsection{Design}

Hold design requires that we design how later the appearance of the application created when used by the user (paud teacher). Making a user friendly design becomes a necessity to make it easy and interesting when used.

\subsection{Implementation}

The implementation phase is the stage where the design that we have created is converted using software to produce an apk file.

\subsection{Testing}

Testing or testing is done by installing the apk file that has become into a smartphone with various types of smartphoen models with different Android versions.

\section{Results and Discussion}

\subsection{The design results with a use case}

Use Case diagram is an approach that is used to illustrate the needs and the flow of programs created [14]. Based on the analysis results, the design results of the design when illustrated with use cases can be illustrated in Figure 1.

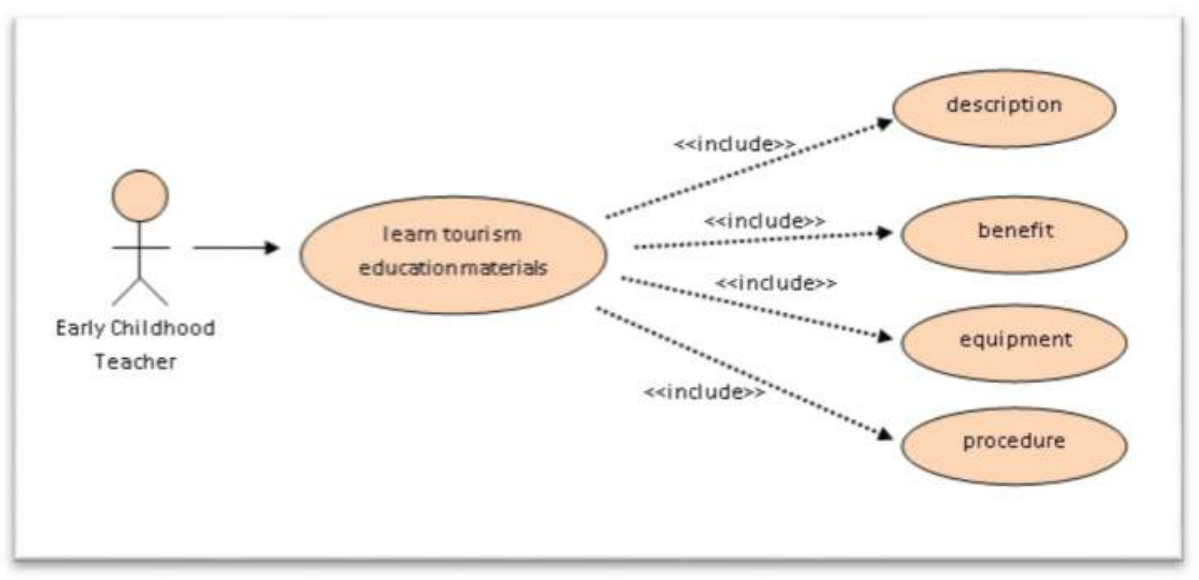

Figure 1. Use Case Diagrams for Tourism Education Application 


\subsection{The concept of android-based tourism education}

Figure 2 describe the fusion of Android-Based Tourism Education. The explanation of android-based tourism education concept are:

a. Early childhood teachers have a conceptualized curriculum related to education. Then the teacher makes a module related to the educational material to be visited, which contains descriptions, benefits, equipment, and rules in the form of soft files.

b. The soft file will be converted into an apk using the Android Book App Maker application.

c. The results of the conversion into an application with the app format.

d. The completed apk are shared with early childhood education teachers who will accompany students.

e. The teachers then install the apk into an Android-based smartphone.

f. Tourism education guidebook already installed can be used during the visit to the intended tour.

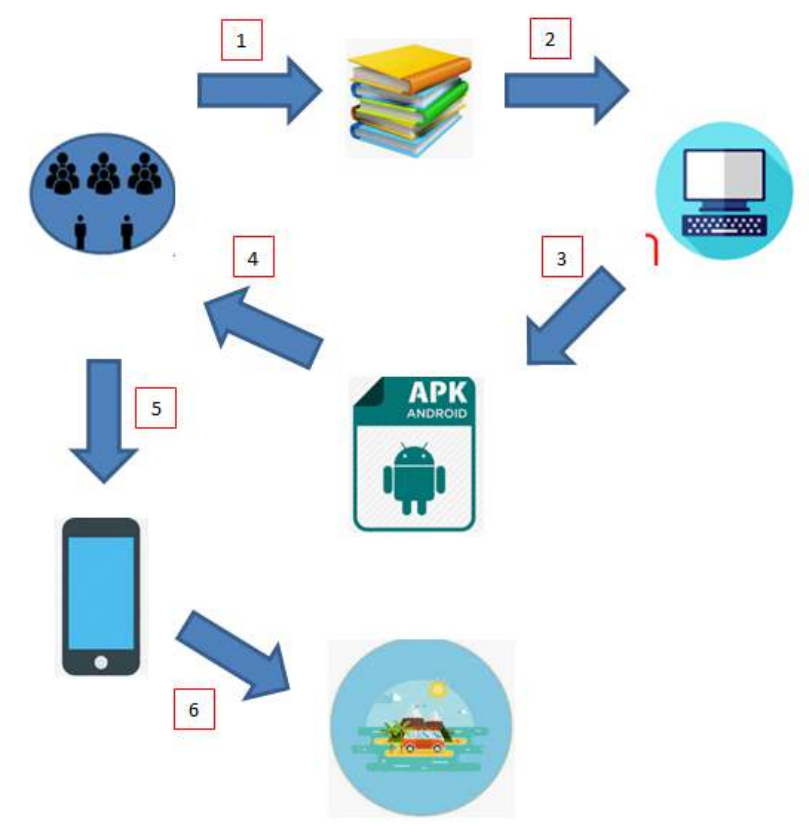

Figure 2. The Concept of Android-Based Tourism Education 


\subsection{Application Display}
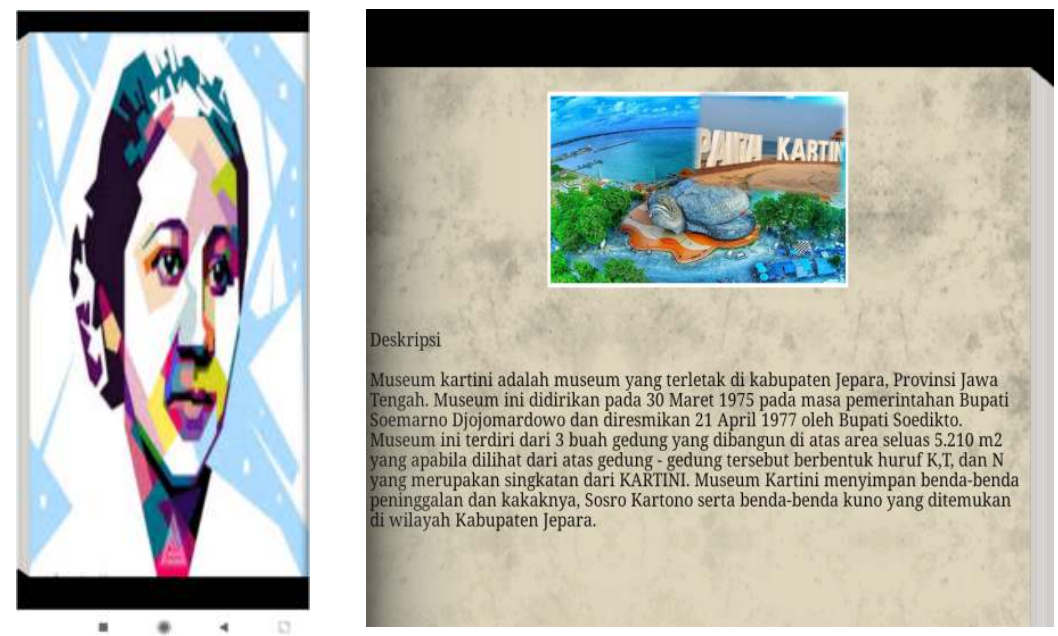

Figure 3. Application Display

Figure 3 is an electronic module of educational tourism in Jepara district, Indonesia with several tourist destination destinations, one of which is Kartini Beach. Looks like a book that can be turned the page (flip).

\subsection{Testing}

The results of testing the application when installed and running using a different version of Android denotes the results that the app can be installed, the display is ok, and no force close occurs. This shows the application does not experience problems and can be used by many teachers who have different specification devices.

Table 1. The tourism education app test results use different smartphones and Android versions

\begin{tabular}{|c|c|c|c|c|c|}
\hline \multirow{2}{*}{ No } & \multirow{2}{*}{ Smartphone } & \multirow{2}{*}{ Specifications } & \multicolumn{3}{|c|}{ Testing Results } \\
\hline & & & Compatible & Display & Force Close \\
\hline 1 & Asus Zenfone 2 & Android 4 Kit Kat & Yes & Ok & No \\
\hline 2 & Sony Xperia Z4 & $\begin{array}{l}\text { Android } 6 \\
\text { Marsmellow }\end{array}$ & Yes & $\mathrm{Ok}$ & No \\
\hline 3 & Redmi Note 7 & Android 9 Pie & Yes & Ok & No \\
\hline
\end{tabular}

\section{Conclusion}

The quality of education can be improved by using assistive technology, making paper modules less. The electronic tourism education module can be made into an Android application that can be used with different devices. This makes educational activities carried out in early childhood education places easier and more efficient. 


\section{References}

[1] Natawidjaja, R., dkk. 2007. Rujukan Filsafat, Teori dan Praksis. Bandung: UPI Press.

[2] Siswanto. 2006. Perkembangan Masyarakat \& Keluarga dalam PAUD. Jakarta: Buletin PAUD.

[3] Kemdikbud. 2014. Peraturan Menteri Pendidikan dan Kebudayaan Nomor 137 Tahun 2014 tentang Standar Nasional Pendidikan Anak Usia Dini, Jakarta: Kementrian Pendidikan dan Kebudayaan

[4] Depdiknas. 2007. Peraturan Menteri Pendidikan Nasional Republik Indonesia, Nomor 16 Tahun 2007 tentang Standar Kualifikasi Akademik dan Kompetensi Guru, Jakarta: Departemen Pendidikan Nasional

[5] Mukminin, A. 2011. Manajemen Penyelenggaraan Pendidikan Anak Usia Dini. Semarang: FIP UNNES.

[6] Asosisaso Penyelenggara Jasa Internet Indonesia, 2018, Pengguna dan Prilaku Internet di Indonesia, Edisi 23 April, Jakarta

[7] Fadlillah, M. 2012. Desain Pembelajaran PAUD. Jogjakarta: Ar-Ruzz Media.

[8] Rusman. 2012. Model-Model Pembelajaran Edisi 2. Bandung: PT. Grafindo Persada

[9] Dimarzio, J. 2008. "Android ${ }^{\mathrm{TM}}$ A Programmer's Guide". The McGraw-Hill Companies

[10] Utami, A, S,N,, 2018, Potensi Pengembangan Promosi Eduwisata Tehsarongge Dalam Penerapan Value Green Tourism Di Desa Sarongge, Pacet Jawa Barat.Jurnal Hospitaly dan Pariwisata, Vol 4 No 1, 88-94

[11] Rahayu, R. 2017. Pembelajaran Matematika Realistik Indonesia BerbasisKeunggulan Lokal Untuk Membangun Disposisi Matematis dan Karakter Cinta Tanah Air. Prosiding Seminar Nasional PGSD Universitas Muria Kudus, 152-163.

[12] Ulya, H. \& Rahayu, R. 2017. Uji Kelayakan Perangkat Pembelajaran ProbingPrompting Berbasis Keunggulan Lokal Kudus. Prosiding Seminar Nasional FKIP Universitas Kristen Satya Wacana, 379-388.

[13] Roger S. Pressman, P. D. (2010). Software Engineering A Practitioner's Approach $7^{\text {th }}$ Edition. (McGraw-Hill, Ed.). New York: Raghothaman Srinivasan

[14] Kurniawan, T, A., 2018, Pemodelan Use Case (UML): Evaluasi Terhadap Beberapa Kesalahan Dalam Praktik, Jurnal Teknologi Informasi dan Ilmu Komputer (JTIIK) Vol 5 No $177-86$ 